\title{
THE ACQUISITION OF RUSSIAN GRAMMAR CASES BY BRAZILIAN STUDENTS
}

\author{
Joao Paulo Sabadin Santos T. Medina \\ Pushkin State Russian Language Institute, Russian Federation \\ Ekaterina Budnik \\ Moscow State Linguistic University, Russian Federation
}

\begin{abstract}
The analysis of Russian discourse in the proficiency levels B1 and B2 points out to Brazilian students' assimilation problems regarding the grammar cases. Such problems are interpreted based on the structural comparison between the verb-object relations in Portuguese and Russian: - the verb and object may be connected directly or through a preposition; - the meaning is also intermediated by the grammar cases. To establish interlinguistic equivalents, they are compared structures with similar meaning in the native language compared to the learnt one. The research aims to understand through an empirical approach to Brazilian students' difficulties when learning grammar cases regarding their native language interference. The authors recorded interviews with Brazilian students in the referred proficiency levels, which were considered under the typological comparison; a questionary answered by the same students was then implemented to confirm such difficulties. The results indicate the structural divergence and consequent difficulty of Brazilian students to acquire the Dative and the Instrumental cases when a preposition does not intermediate the verb-object relation.
\end{abstract}

Keywords. Russian as a foreign language, grammar comparison, grammar cases, typological comparison, Brazilian Portuguese.

\section{Introduction}

The acquisition of grammar cases is a well-known difficulty for students of Russian as a foreign language (RFL). Not only the noun endings need to be assimilated, but also the corresponding meaning. Although frequently, the meaning aspect is left on the second plain due to complexity, both must be equally reinforced. It is precisely through the meaning that the structures to be learned can be understood and apprehended by the student, who inevitably comes to compare the constructions in the learning language to the ones in his/her native language. In this way, the structural comparison based on meaning equivalents is the key to understanding the students' difficulties in learning Russian grammar cases. 
In methodological practice in the study of cases, two ways are proposed: from form to content and from content to form. Proponents of the communicative-activity approach suggest studying cases from meaning to form (inductive path), for example, first show the text (phrase), tell what it is: I do not have a dictionary (negation of something). Then talk as it is expressed: from meaning to form - and again with meaning (Akishina \& Kagan, 2008). Supporters of the conscious-practical and nationally oriented methods are offered when the case study goes from form to meaning (deductive way). For example, V. N. Wagner advises when studying the first case forms - Prepositional, Accusative cases - go from meaning to form. When introducing the mentioned cases go from form to meaning (Vagner, 1995). We believe it is advisable to use the inductive path (from examples to rule) when explaining grammatical material to speakers of typologically close languages.

From our point of view, the effectiveness of mastering the Russian case system requires a conscious understanding meaning expressed by certain case forms, the formation in the minds of students of a connection between the form specific case and its meaning, understanding the syntactic function of Russian nouns in a sentence. And the shortest and most reliable way to disclose the case systems are a comparison with the native language of students.

\section{Literature Review}

The apprehension of Russian grammar cases was approached by the authors of this article in another paper "Linguistic errors of Brazilian students when learning Russian as a foreign language (basic level)”. In this work the typological comparison points out to the potential problem of acquisition of grammar cases, when they differ the equivalent in Portuguese from the structure in Russian, e.g. a verb object is indirect in Russian and direct in Portuguese (Budnik, Medina \& Medina, 2020).

According to L.S. Kriuchkova in the students' conscience are already formed the concepts of time and space, actions, subject and object of the action, quantity, reason, finality, consequence, reality and irreality. However, such concepts are expressed differently in their native language. That is why the student must study the morphological specifics of the studied language and reflect on the semantics of each linguistic form and its functional characteristics (Kriuchkova, 2017). Such cognitive acquisition, naturally, occurs in a different way to students of each nationality, due to their particular linguistics concepts.

The analysis of Russian textbooks directed to Brazilian students reveals the inefficiency of grammatical explanations, including the ones regarding grammar cases, as already exposed in our previous work. The textbooks "Self-Tutorial of Russian” (Dolenga, 1955), Oliveira’s “Russian language course” (Oliveira, n. d.), 
N. Potapova's "Short Russian Language Course" (Potapova, 1961) and T. Castro’s "Speak Russian” (Castro, 2005) present basic methodological issues, as exposed in our last cited work (Budnik, Medina \& Medina, 2020, p. 506).

\section{Methodology}

In order to compare semantic and functional characteristics to the language acquisition of Russian by Brazilian students, we compared the verb-object meanings from the studied with the ones from the native language. The meanings classification elaborated by I. P. Kuzmin and N M. Lariokhina in the compilation of exercises "Padezhi! Ah, padezhi!", not directed to a specific nationality, was applied to the meaning equivalents in Portuguese.

The meaning comparison between the verb-object relations in Portuguese and Russian points out to Russian's particularity of the indirect compliment without a preposition, which concerns the grammar cases genitive, Dative, and instrumental. Such meanings were chosen in order to prove the grammar interference from Portuguese in the acquisition of Russian.

The grammatical interference was checked in two stages. The first was an interview in which the students were stimulated to talk spontaneously and eventually used the targeted structures. The second one was a questionnaire with multiple choices of verb complement regarding the analysed structures.

\section{Experiment and Research Results}

The recorded spontaneous speech of Brazilian students was stimulated by questions about themselves:

Расскажите о себе. Кто Bbl по профессии? Откуда Вы? Чем Вы занимаетесь? 'Tell about yourself. What is your profession? Where are you from? What do you do?'

Что Вы делаете в свободное время? 'What do you do in the free time?'

Почему Вы решили учить русский язык? 'Why did you decide to study the Russian language?'

Каких русских авторов Bы предпочитаете? Какое у вас любимое произведение русской литературыз? 'Which Russian authors do you prefer? What is your favourite piece of Russian literature?'

Вы уже были в России? Если да, то как прошла ваша поездка? Если нет, Вы собираетесь туда? Какие у Вас ожидания от этого путешествия? 'Have you been in Russia? If you did, how was your trip? If you did not, are you planning to go there? What do you expect from this trip?'

From the diverse types of divergence from the discourse in Russian of a native we chose to analyse, for now, the verb-object relations when not 
intermediated by a preposition. To confirm the identified divergences, we elaborated a questionnaire in Google Form containing 24 sentences with the missing compliment to be chosen from 4 options, of which only one was correct. An option containing the alternative "Я не знаю." - "I don "t know." was included to stimulate the students not to choose an option when they had no idea of the answer.

We added two questions of each meaning analysed. From the Dative, ten questions were given to the students concerning five different meanings:

1) speech act and addressee teacher.'

Студент дал яблоко преподавателю. 'The student gave an apple to the

Мама сказала сыну спокойной ночи. 'The mother told to the son good night.'

2) cooperation

Сама всегда помогает друзьям. 'Sacha always helps the friends.'

Я попросил, но Ваня не помог мне. 'I asked, but Vanya didn't help me.'

3) betrayal

Муж изменил жене. Поэтому, они развелись. 'The husband has cheated on the wife. For this reason, they separated.'

Старик не изменил идеалам своей юности, но остался верным самому себе. 'The old man has not betrayed the ideals from his youth, but has remained true to himself.'

4) emotional relation

Дети обычно радуются Рождеству. 'The kids usually rejoice at Christmas.'

Мама удивилась мальчику, когда она узнала насколько он способен. 'Тhe mother was surprised with the kid when she found out how much he could do.'

5) jealousy

Мы с коллегами завидуем начальнику, потому что у него шикарная машина. 'My colleagues and I envy the boss because he has a fancy car.'

Никто не завидовал Рите, когда она работала в новогодние праздники. 'Nobody has envied Rita, when she worked in the New Year holiday.'

Since the last meaning may be similar to the fourth one in Russian, but not in Portuguese, we added two questions separately.

From the Genitive were given to the students 6 questions regarding 3 meanings:

1) concern

Школьник боится экзамена по математике. 'The schoolboy is afraid of the math test.'

Девочка очень смелая, она не боится темноты. 'The girl is very brave, she is not afraid of darkness.' 
2) embarrassment

Мальчик стеснялся того, что мама почеловала его на глазах у друзей. 'The boy was embarrassed that his mother kissed him in front of his friends.'

Друзья всегда стесняются поведения Саши, когда она хвастается. 'The friends are always embarrassed of Sasha's behaviour, when she shows off.'

3) request

Преподаватель просит учеников не шуметь во время занятий. 'The teacher asked the students not to make noise during the lessons.'

Саша попросила незнакомого о помощи. 'Sasha asked a stranger for help.'

The Instrumental was represented in the questionnaire with 8 questions for 4 different meanings:

1) possession, distraction

Мальчик уже владеет русским языком, благодаря его русской маме. 'The boy already masters the Russian language, thanks to his Russian mother.'

Команда отличается тем, что ещё не проигрывала в этом году. 'Тhe team differs in that has not lost this year.'

2) emotional relation

Турист хотел наслаждаться путешествием, но всё пошло не так. 'Тhe tourist wanted to enjoy the travel, but everything went sideways.'

Пара всегда гуляет по парку, они могут весь день любоваться природой. 'The couple always walk the park, they could admire the nature all day.'

3) utilization

Хороший игрок знает, как пользоваться своими сильными сторонами. 'A good player knows how to use his strengths.'

Во время экзамена запрещено пользоваться телефоном. 'During the exam it is forbidden to use the telephone.

4) management, administration

Директор руководит сектором. 'The director manages the sector.'

Иван Сергеевич управляет корпорацией. 'Ivan Serguéevitch administers the corporation.'

The errors may be of two different natures: from an ending misplacement, either from a meaning ignorance. The first option can be excluded in our research because of the accuracy when choosing objects in other meanings of the three analysed cases.

We analysed the meanings in which were found most recurrent object errors in sentences answers. The chosen alternatives indicate conclusive results only in three of the twelve analysed meanings, which makes possible to conclude that the Brazilian student can learn the primary meanings of Genitive, Dative and Instrumental, but finds difficulties to extend such meanings endings to specific groups of verbs of the correspondent cases. 
We found few errors in the meanings of speech act and addressee and the Dative's cooperation, which allows concluding that these meanings are well assimilated. We found a medium number of errors in the meanings of jealousy in the Dative, concern and request of possession/distinction in the Genitive, and emotional relation and utilisation in the Instrumental. In these situations, the errors are not enough to be considered as interference from the Portuguese.

On the other hand, the high incidence of errors shows that there is confusion regarding some meanings:

7. Муж изменил , поэтому они развелись.

29 responses

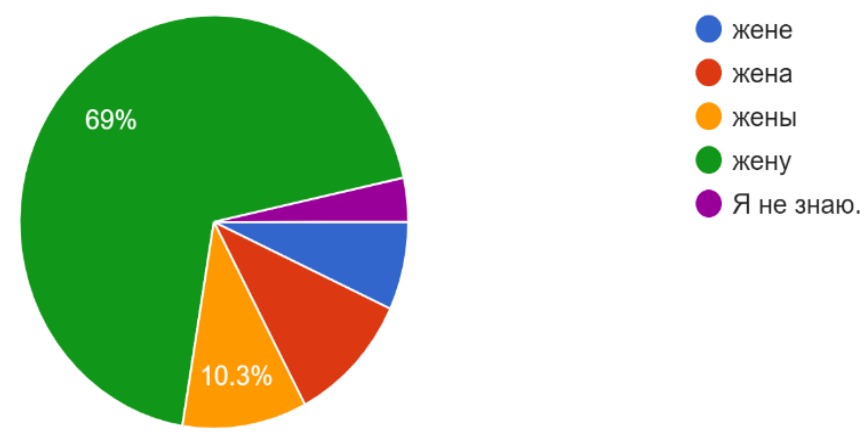

Figure 1 "The husband has cheated on the wife. For this reason they separated."

27. Старик не изменил своей юности, а остался верным самому себе.

29 responses

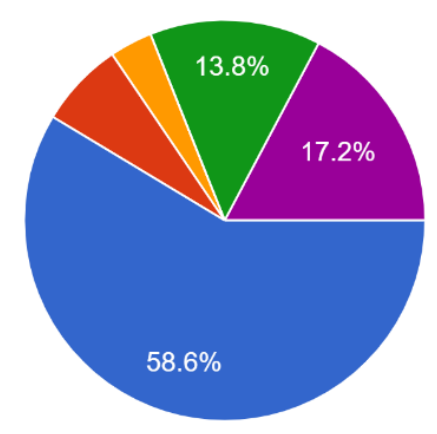

идеалы

идеалам

иделов

идеалами

Я не знаю.

Figure 2 "The old man has not betrayed the ideals from his youth, but has remained true to himself." 


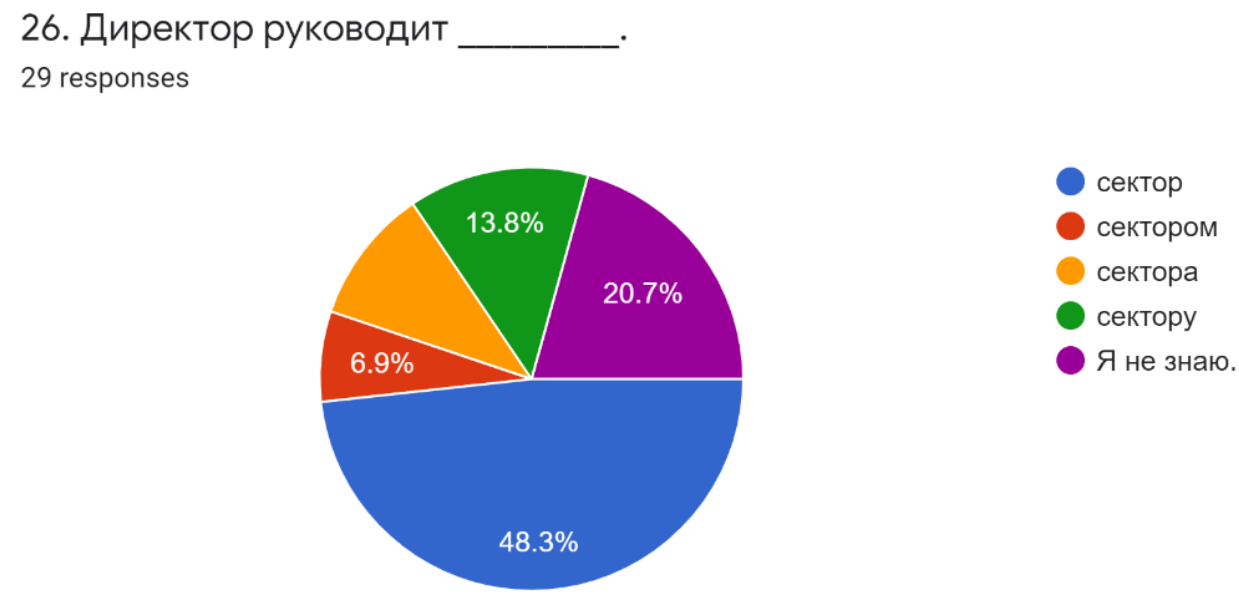

Figure 3 “The director manages the sector."

31. Иван Сергеевич управляет

29 responses

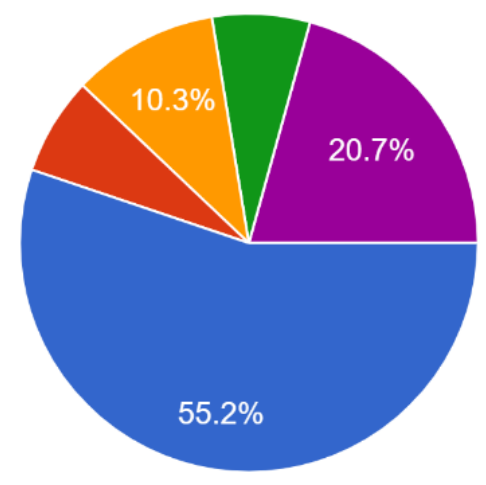

корпорацию

корпорация

корпорацией

корпорации

Я не знаю.

Figure 4 "Ivan Serguéevitch administers the corporation."

The equivocated objects жену 'wife' and идеаль 'ideals' to the verb изменить 'to betray' mark an option of the Accusative instead of the Dative, what also happens in the objects сектор 'sector' and корпораиию 'corporation' to the verbs руководить 'to rule' and управлять 'to manage' in the Accusative instead of the Instrumental. The correspondent verbs in Portuguese trair, comandar e gerir establish direct relations with the object, what explains the option for Accusative forms in Russian.

On the other hand, the next graphics show another kind of case misplacement: 
9. Дети обычно радуются

29 responses

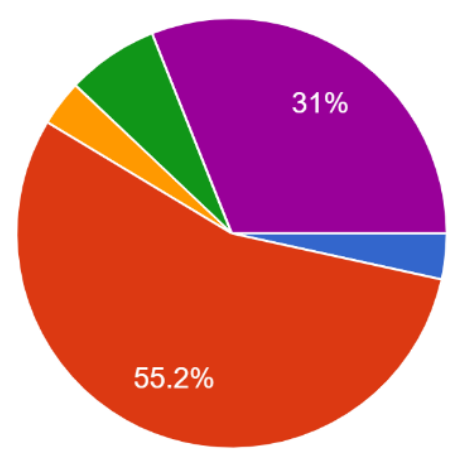

Figure 5 "The kids usually rejoice at Christmas."

10. Мама удивилась когда она узнала насколько он способен.

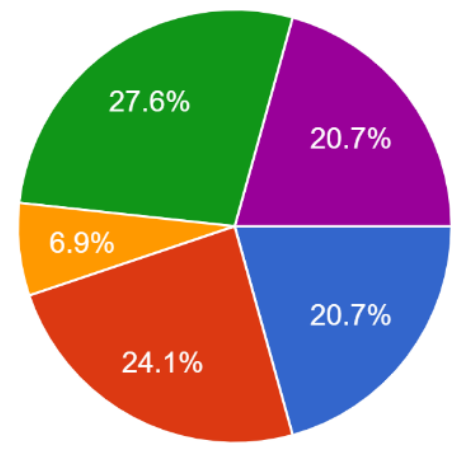

Figure 6 "The mother was surprised with the kid, when she found out how much he could do."

The option of the students $c$ Рождеством 'with Christmas' and $c$ мальчиком 'with the boy' as objects to the verbs радоваться 'to get happy' and удивляться 'to get surprised' indicates the apprehension of the meaning of emotional relation as Instrumental instead of Dative. The correspondent verbs in Portuguese alegrar-se and surpreender-se have object intermediated by the preposition com 'with', correspondent to the Russian $c$.

Such a pattern of errors proves the influence of the native language in the acquisition of the learned one. 


\section{Conclusions}

The questionnaire results point out to a pattern of errors when using the Dative and the Instrumental among Brazilian students. When you learn Russian cases, you need to pay attention on the form (endings and prepositions) and on the meaning of each case. However, it is not sufficient to attribute such errors exclusively to this nationality, because it would be necessary to apply the same questions to students of other nationalities. Therefore, it consists in a step to explore the native language interference in the acquisition of Russian cases.

Based on the difficulties showed by the students to assimilate the Dative and the Instrumental, at first, we propose to teach the structures that contain preposition and at a second stage present the ones without preposition. This way the student can understand better the case meaning, as well as the corresponding endings, and then assimilate the more difficult structures, the ones in which there is no preposition to indicate the object case.

\section{References}

Akishina, A. A., \& Kagan, O. E. (2008). Uchimsja uchit': dlja prepodavatelja russkogo jazyka kak inostrannogo. Moscow: Russkij jazyk.

Budnik, E. A., Medina J. P., \& Medina S. M. (2020). Linguistic errors of Brazilian students when learning Russian as a foreign language (basic level). Society. Integration. Education. International Scientific Conference, 2020, Rezekne Academy of Technologies. Volume V, 505-520. DOI: https://doi.org/10.17770/sie2020vol5.5097

Castro, T. (2005). Fale russo. Porto Alegre: Ediplay.

Dolenga, M. (1995). A língua russa. Gramática elementar. Rio de Janeiro: Globo.

Krjuchkova, L. S. (2018). Padezhnaja i predlozhno-padezhnaja sistema russkogo jazyka: funkcional'no-semanticheskij aspekt. 3-e izd. Moscow: FLINTA Nauka.

Kuzmin, I. P., \& Lariokhina, N. M. (2018). Padezhi! Ah, padezhi! Sbornik uprazhnenij po glagol'nomu upravleniju. Moscow: Russkij jazyk. Kursy.

Oliveira, B. E. (n. d.). Curso de russo: do básico ao avançado. RussiaNet. Retrieved from: http://files.brasilpage.webnode.com.br/200000013-aec4faf3f4/Russo\%20-

\%20Curso\%20Completo.pdf

Potapova, N. (1961). Breve manual de língua russa. Moskva: Edições em línguas estrangeiras.

Vagner, V. N. (1995). Metodika prepodavanija russkogo jazyka anglogovorjashhim i frankogovorjashhim. Fonetika. Grafika. Chasti rechi. Moscow: Izd-vo RUDN. 